\title{
Numerical and Experimental Analysis of the Real Load Arising in the Cushion of the Car Seat
}

Petr Kulhavý ${ }^{1,2}$, Pavel Srb ${ }^{1,2}$, Michal Petru ${ }^{1,2}$

${ }^{1}$ Faculty of Mechanical Engineering, Technical University of Liberec, Studentská 2, 461 17, Liberec 1, Czech Republic. E-mail: petr.kulhavy@tul.cz,pavel.srb@tul.cz,michal.petru@tul.cz

${ }^{2}$ Institute for Nanomaterials, Advanced Technology and Innovation, Technická univerzita v Liberci, Studentská 2, 461 17, Liberec 1, Česká republika. E-mail: petr.kulhavy@tul.cz, michal.petru@tul.cz, pavel.srb@tul.cz

Nowadays people spend still more of their life on the road. Vehicles has been becoming increasingly sophisticated and the main direction of their development is placed primarily into the areas of environment, design, safety and comfort. This work focuses primarily on the last-mentioned point, and that's seating comfort and the phenomena with straight influence on the transported persons. Probably with any of car elements, isn't the person in a direct contact to much as with the seat and therefore the seats and their innovation are still in considerable interest of the customers and manufacturers. This work deals with description of the resulting tensions and distribution of the specific pressures in the cushion of a car seat and also describe the creation of an appropriate computational model.

Based on the real transmission data, that was measured during driving a car, has been carried out an experimental measurements of static and dynamic loading of the overall stiffness and response of the system. Subsequently, depending to the real CAD data were compiled the boundary and materials conditions that describe the statical FEM model of the polyurethane cushion. For the quasi static load was carried out the experimental measurements on a mechanical pulsator, that is suitable for assessing the viscoelastic and hysteresis effects inside the materials. The found results have been verified with using the $x$-sensor on a model of real human back during the scanning of its specific contact pressure.

Keywords: Car seat, PUR foam, contact pressure, x-sensor, biomechanic

\section{Acknowledgements}

This work was supported by the Ministry of Education of the Czech Republic within the SGS project nr. 21007 on the Technical University of Liberec.

\section{References}

[1] SRB, P. (2014). Research of the low density composite foams of car seats. Ph.D. thesis. TU v Liberci, KST, Liberec, p. 21

[2] VALASEK, P., MULLER, M. (2013). Changes of Polyurethane Mechanical Properties Filled with Glass Powder. In: Manufacturing Technology, vol. 13, No. 4, 2013

[3] RADUŠKOVÁ, M. (2009). Marketing research of comfort seating in automobiles. Technical university of liberec.

[4] PETRU, M. (2012). Car seat with non-polyurethane material. Ph.D. thesis. TU v Liberci, KST, Liberec, p. 122

[5] PETříK, J. (2008). Interaction of a car seat and load. Ph.D. thesis. TU v Liberci, KMO, Liberec, p. 125

[6] MARTONKA, R. (2009). Measuring characteristics of automotive seats and their innovation, Ph.D. thesis. TU v Liberci, KST, Liberec, p. 117

[7] SEGLA, S., ORECNY,M., TRISOVIC, N. (2013). Passive Seat Suspension With a Vibration Absorber. In: Manufacturing Technology, vol. 13 No 4, 2013

[8] FOYE, R.L. (1966). Compression strength of unidirectional composites, Columbus, American Institute of Aeronautics and Astronautics, Structural composites group,USA.

[9] MASNFELD, N. J. (2005). Human response to vibration, CRC Press.

[10]FLIEGEL, V., MARTONKA, R. (2008). Automobile seats - simulation characteristics seats. In: Zb. Medzin. konferencie Modelovanie mechanickych a mechatronickych sustav MM aMS, TU Košice. Acta Mechanica

[11]Petřik, J. (2007). FE model of the foam cushion. Plzeň, ISBN 978-80-7043-597-7

[12]PETRŮ, M., NOVÁK, O. (2010). Mechanical properties measurement and comparison of polyurethane foam substitute, ACC Journal, 16, Issue A, Natural Sciences and Technology, p. 50-59. 
[13] NEILSEN, M.K., MORGAN, H.S., KRIEG, R.D. (1987). A Phenomenological Constitutive Model for Low Density Polyurethane Foams, SANDIA Report, SAND86-2927,UC-71

[14]DIZO, J. (2014). Evaluation of Ride Comfort for Passengers by Means of Computer Simulation. In: Manufacturing Technology, vol. 15 No 1, 2014

[15]SRB, P., KULHAVÝ, P., MARTONKA, P. (2014). Assessment of the Mechanical Properties the polyurethane Foam under multiaxial Loading in a different climatic conditions. In: ICMD 2014. Beroun, Czech Republic, Prague: Czech Technical University, 2014. ISBN 978-80-01-05542-7.

[16]FLIEGEL, V. (2005). Study of car seat and human rheology. In 46. Mezinárodní konference kateder částí a mechanismů strojů, TU v Liberci. 2005. p. 125 - 128. ISBN 80-213-1523-7

[17]Low density foams [online] Available from: http://msdssearch.dow.com/PublishedLiteratureDOWCOM/dh_030b/0901b8038030b1 d4.pdf?filepath=automotive/pdfs/noreg/299-51549.pdf

[18]ČSN ISO 2631-1: Vibrace a rázy - Hodnoceni expozice člověka celkovým vibracím 